\title{
Influência da irrigação, nas épocas seca e chuvosa, na produção e composição química dos capins napier e mombaça em sistema de lotação intermitente ${ }^{1}$
}

\author{
Enilson Geraldo Ribeiro ${ }^{2 *}$, Carlos Augusto de Alencar Fontes ${ }^{3}$, Jorge Guilherme Bergottini \\ Palieraqui $^{2}$, Antônio Carlos Cóser ${ }^{4}$, Carlos Eugênio Martinss ${ }^{4}$, Roberto Carneiro da Silva ${ }^{5}$
}

\author{
1 Projeto financiado pela Fundação de Amparo à Pesquisa do Estado do Rio de Janeiro (FAPERJ). \\ 2 Programa de Pós-graduação em Produção Animal - UENF. \\ ${ }^{3}$ UENF. \\ ${ }^{4}$ Embrapa Gado de Leite. \\ ${ }^{5}$ Bolsista de Iniciação Científica.
}

RESUMO - O experimento foi conduzido com o objetivo de avaliar a influência da irrigação sobre as disponibilidades de matéria seca total (DMST), matéria seca verde (DMSV) e matéria seca residual (DMSR); a altura; a densidade volumétrica da forragem (DV); a porcentagem de folhas e a composição química da lâmina foliar dos capins napier e mombaça. Avaliaram-se as combinações das duas forrageiras com dois níveis de irrigação (presença e ausência). A irrigação foi realizada repondo $100 \%$ da evapotranspiração $\left(\mathrm{ET}_{0}\right)$ média diária observada em dez anos. Adotou-se o sistema de lotação intermitente, com quatro dias de ocupação e 32 de descanso e carga animal variável, mantendo-se pressão de pastejo de $4 \mathrm{~kg}$ de matéria seca foliar disponível (MSFD)/100 kg de peso vivo, utilizando-se novilhos. Os maiores valores de disponibilidade de matéria seca total e matéria seca verde e matéria seca residual, nas duas épocas do ano, foram obtidos com as forrageiras irrigadas e o capim-napier. A irrigação trouxe maior aumento nas disponibilidades de matéria seca total e matéria seca verde no capimmombaça que no capim-napier. Na época seca, a irrigação elevou a porcentagem de folhas, a altura e a densidade volumétrica de forragem. Nas épocas seca e chuvosa, o capim-napier, irrigado ou não, teve menor porcentagem de folhas e maior altura que o capim-mombaça, mas a densidade volumétrica de forragem não diferiu entre as duas forrageiras. Na época chuvosa as forrageiras sob irrigação apresentaram maior altura, mas a porcentagem de folhas e a densidade volumétrica de forragem foram semelhantes às obtidas com as forrageiras não irrigadas. A irrigação não influenciou os teores de matéria orgânica, proteína bruta e fibra em detergente neutro. O capim-napier, irrigado ou não, apresentou maior teor de proteína bruta e menores teores de matéria orgânica e fibra em detergente neutro em comparação ao capim-mombaça, nas duas épocas.

Palavras-chave: gramíneas tropicais, pastagens irrigadas, qualidade da forragem

\section{Influence of irrigation upon biomass production and chemical composition of Napier grass and Mombaça grass under rotational grazing during the dry and rainy season}

\begin{abstract}
The research was carried out aiming to evaluate the influence of irrigation on total dry matter (TDMA) and green dry matter availability (GDMA) and on residual dry matter (RDM), forage height, forage density (FD), leaf percentage and chemical composition of leaf blades of the Napier grass and Mombaça grass. The treatments were the combinations of the two grasses and two irrigation levels (presence and absence). The irrigation supplied the previous ten-year mean evapotranspiration $\left(\mathrm{ET}_{0}\right)$. It was adopted the rotational grazing, with grazing period of four days, rest period of 32 days and variable stocking, with grazing pressure of four $\mathrm{kg}$ of leaf dry matter per $100 \mathrm{~kg}$ live weight. Irrigated forages, in relation to non irrigated, and Napier grass, in relation to Mombaçagrass, showed higher TDMA, GDMA and RDM in both seasons of the year. Mombaça grass showed higher response to irrigation in TDMA and GDMA than Napier grass. During the dry season, irrigation increased percent of leaves, forage height and forage density. Napier grass, irrigated or not, in both seasons, was taller, showed lower proportion of leaves, but did not differ from Mombaça grass with respect to density. During the rainy season, irrigated forages were taller, but did not differ from the non irrigated ones regarding to percent of leaves and density. Irrigation had no influence on organic matter (OM), crude protein (CP) and neutral detergent fiber (NDF) content of forages. Napier grass, irrigated or not, had higher CP and lower OM and NDF than Mombaça grass, in both seasons.
\end{abstract}

Key Words: forage quality, irrigated pastures, tropical grasses 


\section{Introdução}

A irrigação de pastagens foi introduzida inicialmente com o objetivo de reduzir a estacionalidade de produção de forragem na época seca. No entanto, alguns autores (Alvim et al., 1986; Marcelino et al., 2003) observaram que a estacionalidade em forrageiras tropicais não reduz em resposta à irrigação e atribuíram o resultado a limitações impostas pela temperatura e luminosidade nessa época. As forrageiras tropicais têm crescimento muito reduzido quando expostas a temperaturas menores que $16^{\circ} \mathrm{C}$ (Whitheman, 1980). Por outro lado, segundo Corsi \& Martha Jr. (1998) é possível manter, no outono-inverno, taxa de lotação animal de 40 a $60 \%$ daquela observada no verão em pastagem irrigada manejada intensivamente contra 10 a $20 \%$ em pastagem não irrigada.

Mesmo durante a época chuvosa, a correção da deficiência hídrica nos períodos de veranico pode trazer aumento substancial da produção forrageira, o que sugere haver potencial de uso da irrigação de pastagens durante o ano todo, quando as condições de fertilidade do solo e de temperatura e fotoperíodo durante o inverno não são limitantes (Maya, 2003).

As condições climáticas da Região Norte Fluminense, incluindo a temperatura, na época seca, a luminosidade e a ocorrência de veranicos sinalizam potencial para adoção dessa prática na região durante o ano todo (Palieraqui et al., 2006).

Entre as gramíneas forrageiras tropicais, destacam-se pela produtividade e valor nutritivo, os cultivares de capim-elefante (Pennisetum purpureum Schum.) e a espécie Panicum maximum Jacq.. Na espécie P. maximum destacam-se atualmente os cultivares Tanzânia e Mombaça (Santos et al., 1999).

Objetivou-se, com esta pesquisa verificar a influência da irrigação sobre as disponibilidades de matéria seca total, matéria verde seca e matéria seca residual, a altura do dossel, a densidade volumétrica da forragem e a composição química da lâmina foliar dos capins napier e mombaça sob lotação intermitente.

\section{Material e Métodos}

O experimento foi conduzido na UENF, em Campos dos Goytacazes, região norte do estado do Rio de Janeiro. Foram estudadas as respostas dos capins elefante cv. Napier (Pennisetum purpureum) e Mombaça (Panicum maximum) à irrigação durante as épocas seca e chuvosa. $\mathrm{O}$ município apresenta coordenadas geográficas de $21^{\circ} 44^{\prime} 47^{\prime \prime}$ de latitude Sul e $41^{\circ} 18^{\prime} 24^{\prime \prime}$ de longitude Oeste e altitude de
12 m. O padrão climático da região é descrito como Aw, tropical quente úmido, com período seco no inverno e chuvoso no verão (Köppen, 1948).

O experimento compreendeu duas épocas de seca (junho a outubro 2002 e maio a outubro de 2003) e uma época chuvosa (novembro de 2002 a abril de 2003), com quatro ciclos de pastejo em cada época. Os capins Napier e Mombaça foram plantados na época chuvosa de 2001/ 2002. Antes do plantio, a saturação de bases do solo foi corrigida para $60 \%$, com a aplicação de calcário dolomítico. $\mathrm{Na}$ ocasião do plantio, foram aplicados $100 \mathrm{~kg} / \mathrm{ha} \mathrm{de} \mathrm{P}_{2} \mathrm{O}_{5}$, na forma de superfosfato simples, e 30 dias depois foi feita adubação em cobertura com nitrogênio e potássio, aplicando-se $50 \mathrm{~kg} / \mathrm{ha} \mathrm{N}$ (sulfato de amônio) e $40 \mathrm{~kg} / \mathrm{ha} \mathrm{de}$ $\mathrm{K}_{2} \mathrm{O}$ (cloreto de potássio). No decorrer do período experimental, foram realizadas adubações de manutenção, com aplicação de nitrogênio, $400 \mathrm{~kg} / \mathrm{ha} /$ ano (sulfato de amônio), e cloreto de potássio, $200 \mathrm{~kg} / \mathrm{ha} /$ ano de $\mathrm{K}_{2} \mathrm{O}$, parcelados igualmente após a saída dos animais. As quantidades de corretivo e de fertilizantes utilizadas no estabelecimento e na manutenção das pastagens foram definidas de acordo com a produtividade animal pretendida e as características do solo (textura e composição química de cada bloco), de acordo com as recomendações da Comissão de Fertilidade do Solo do Estado de Minas Gerais (CFSEMG, 1999).

Adotou-se o delineamento experimental de blocos completos casualizados (três blocos, com três hectares cada), com parcelas subdivididas no tempo e espaço, com mais de uma unidade experimental por subclasse. Cada bloco com nível de fertilidade diferente foi subdividido em duas parcelas de 1,5 ha, nas quais foram alocadas aleatoriamente as duas forrageiras. Cada parcela (em cada bloco) foi dividida em seis subparcelas de 0,25 ha, distribuídas aleatoriamente entre os dois níveis de irrigação (sem irrigação ou com $100 \%$ da evapotranspiração local, média histórica de 10 anos) com três repetições.

No total, os 9 ha da área experimental foram divididos em 36 piquetes de 0,25 ha, igualmente distribuídos entre os capins napier e mombaça. Assim, as forrageiras foram avaliadas em sistema de lotação intermitente com períodos de ocupação e descanso de, respectivamente, 4 e 32 dias, completando um ciclo de pastejo a cada 36 dias.

As pastagens foram utilizadas por novilhos mestiços F1 Europeu-Zebu $( \pm 260 \mathrm{~kg})$ distribuídos em quatro grupos homogêneos e alocados aleatoriamente nos dois níveis de irrigação. A taxa de lotação foi variável, mantendo-se a oferta de forragem em $4 \%$ (4 kg de matéria seca foliar $/ 100 \mathrm{~kg}$ de peso corporal) para ambos os níveis de irrigação, com o uso de animais reguladores. A taxa de lotação, o ganho de 
peso, a digestibilidade in vivo e o consumo de nutrientes dos animais experimentais foram descritos por Ribeiro et al. (2008).

O emprego do mesmo manejo para as duas forrageiras avaliadas (períodos iguais de ocupação e descanso) foi imposto pela necessidade de se manter sempre um bebedouro exclusivo (mais saleiro e área de sombra) para cada um dos quatro grupos de animais experimentais. Tendo em vista a distribuição balanceada (não contígua) de ambas as forrageiras por toda a área experimental e a exigência da distribuição aleatória dos piquetes nos quatro tratamentos, a adoção de manejos diferenciados para cada forrageira implicaria necessidade de acesso exclusivo à água (mais sal e sombra) em cada um dos 36 piquetes experimentais.

Com a adoção do mesmo manejo para ambas as forrageiras, foi possível conduzir o experimento com apenas cinco conjuntos de bebedouro, sal e sombrite, instalados estrategicamente nos corredores de acesso aos piquetes. Além disso, procurou-se manejar as forrageiras dentro de limites descritos na literatura (Brâncio et al., 2003; Martins et al., 2004).

$\mathrm{Na}$ ocasião do plantio das forrageiras, toda a área experimental foi equipada com um sistema de irrigação de baixa pressão em malha fixa, com espaçamento de $12 \mathrm{~m}$ entre as linhas de pontos de aspersão. Ordenadas longitudinalmente, as linhas possuíam de 6 a 8 pontos fixos de aspersão, dependendo do comprimento do piquete. Nos piquetes irrigados, a lâmina d'água foi aplicada revezando um aspersor entre os pontos de aspersão de cada linha. Nos piquetes testemunhas, todos os pontos de aspersão foram mantidos vedados durante o período experimental. O tempo médio gasto para a irrigação da área experimental foi de sete dias.

Os piquetes experimentais somente se avizinhavam pela cerca lateral e foram separados no sentido do comprimento por corredores ou canais de drenagem. Como os piquetes foram dispostos longitudinalmente, tanto em relação ao vento predominante na região quanto em relação à leve inclinação do terreno, reduziu-se a possibilidade da aplicação involuntária de água nos piquetes testemunhas.

No manejo da irrigação, adotou-se um turno de rega de sete dias. A lâmina d'água aplicada semanalmente foi estabelecida de modo a repor a evapotranspiração média mensal histórica, observada nos dez anos anteriores à pesquisa, deduzindo-se a precipitação pluviométrica ocorrida durante cada período. Os valores médios mensais de evapotranspiração, nos dez anos anteriores à pesquisa, foram obtidos no Campus Avançado da Universidade Federal Rural do Rio de Janeiro, localizado próximo à área experimental, em Campos dos Goytacazes (Tabela 1) e a precipitação pluviométrica foi medida no local do experimento.

Foram avaliadas as disponibilidades de matéria seca total (DMST) e de matéria seca verde (DMSV), a matéria seca residual (MSR), a altura do dossel, a densidade volumétrica da forragem (DV) e a proporção e composição química da lâmina foliar. As variáveis acima foram estimadas em cada um dos 36 piquetes experimentais, em todos os 12 ciclos de pastejo avaliados.

Os procedimentos para a estimação das disponibilidades de matéria seca total e matéria seca verde e densidade

Tabela 1 - Histórico de evapotranspiração de referência $\left(\mathrm{ET}_{0}\right)$, precipitação pluviométrica, temperaturas médias, máximas e mínimas durante o período experimental e lâminas mensais estimadas de irrigação

\begin{tabular}{|c|c|c|c|c|c|c|c|c|c|c|c|c|}
\hline & \multicolumn{12}{|c|}{ Mês } \\
\hline & Jan & Fev & Mar & Abr & Maio & Jun & Jul & Ago & Set & Out & Nov & Dez \\
\hline Evapotranspiração de transferência $(\mathrm{mm})$ & 4,4 & 4,4 & 4,0 & 3,1 & 2,4 & 2,2 & 2,3 & 2,7 & 3,0 & 3,7 & 4,0 & 4,2 \\
\hline Precipitação pluviométrica $(\mathrm{mm})$ & 82,7 & 62,8 & 9,7 & 15,4 & 3,9 & 35,1 & 24,1 & 19,8 & 146,5 & 15,9 & 61,5 & 114,8 \\
\hline Temperatura média $\left({ }^{\circ} \mathrm{C}\right)$ & 25,3 & 25,2 & 26,3 & 24,7 & 23,3 & 22,0 & 20,3 & 22,3 & 20,6 & 24,0 & 24,7 & 25,5 \\
\hline & \multicolumn{12}{|c|}{2003} \\
\hline Precipitação pluviométrica $(\mathrm{mm})$ & 226,8 & 15,5 & 153,3 & 82,1 & 88,4 & 0,4 & 35,2 & 50,3 & 39,3 & 66,9 & 65,9 & 135,8 \\
\hline Temperatura média $\left({ }^{\circ} \mathrm{C}\right)$ & 26,0 & 26,9 & 26,2 & 24,4 & 21,8 & 21,7 & 20,3 & 19,9 & - & - & - & 25,0 \\
\hline Temperatura máxima $\left({ }^{\circ} \mathrm{C}\right)$ & 32,4 & 33,7 & 33,1 & 30,6 & 27,6 & 28,9 & 26,8 & 25,4 & 27,4 & 28,7 & 30,7 & 30,7 \\
\hline \multirow[t]{2}{*}{ Temperatura mínima $\left({ }^{\circ} \mathrm{C}\right)$} & 22,3 & 21,8 & 21,9 & 20,3 & 17,4 & 16,9 & 15,5 & 15,7 & 18,5 & 19,4 & 21,7 & 21,5 \\
\hline & \multicolumn{12}{|c|}{ Lâmina mensal de irrigação estimada $(\mathrm{mm})^{1}$} \\
\hline
\end{tabular}

\footnotetext{
${ }^{1}$ Lâmina de irrigação estimada a partir de valores de média histórica (10 anos) de evapotranspiração (ET 0 ), fornecida pela UFRRJ/Campus Avançado de Campos dos Goytacazes, Rio de Janeiro.
} 
volumétrica de forragem, da porcentagem de lâminas foliares e da altura do dossel foram iniciados no dia anterior à entrada dos animais nos piquetes. Foram realizadas, simultaneamente, mensurações de altura e cortes da forragem, com amostragens sistemáticas na diagonal em cada piquete. Utilizando-se uma régua de madeira graduada em intervalos de $5 \mathrm{~cm}$, foi feita uma leitura da altura do dossel a cada $4 \mathrm{~m}$. A cada três leituras, um quadrado metálico de $1 \mathrm{~m}^{2}$ com um lado aberto foi posto sobre o solo e a forragem delimitada foi cortada a $30 \mathrm{~cm}$ de altura, totalizando 18 mensurações de altura (72/ha) e seis cortes de forragem (24/ha) em cada piquete.

Da biomassa coletada em cada piquete, foi retirada uma subamostra, que foi submetida à separação botânica em lâmina foliar, colmo + bainha e material morto. Estas frações foram pesadas, antes e após a secagem em estufa com ventilação forçada $\left(55^{\circ} \mathrm{C}\right.$ por 72 horas $)$, para determinação de seus teores de matéria seca (MS). Adicionalmente, as amostras das lâminas foliares foram moídas em moinho tipo facas (peneira de 30 mesh) e acondicionadas em recipientes de vidro. Posteriormente, as amostras das lâminas foliares foram analisadas para determinação dos teores de MS (ASE), MO, PB e FDN e da digestibilidade (DIVMS), de acordo com metodologia descrita por Silva \& Queiroz (2002).

Os pesos individuais de cada fração botânica, em $\mathrm{kg} / \mathrm{ha}$ de MS, foram obtidos efetuando-se a multiplicação: peso da biomassa coletada em $6 \mathrm{~m}^{2} \times$ a extrapolação para 1 ha $(10.000 \div 6) \times$ as proporções das frações botânicas (lâmina foliar, de colmo + bainha e de material morto) na biomassa coletada $\times$ os teores de MS das frações botânicas.

A disponibilidade de matéria seca total foi estimada somando-se os pesos individuais de todas as frações botânicas; a disponibilidade de matéria seca verde foi estimada somando-se os pesos individuais da lâmina foliar e do colmo + bainha. Dividindo-se o peso individual da lâmina foliar pela disponbilidade de matéria seca total, foi obtida a proporção de folhas. A altura do dossel correspondeu ao valor médio das 18 leituras realizadas em cada piquete; e a densidade volumétrica de forragem foi calculada por meio da divisão: DMSV $\div$ (altura do dossel $30 \mathrm{~cm}$, correspondente à altura do corte).

Os procedimentos para estimação da matéria seca residual foram iniciados no dia seguinte à saída dos animais dos piquetes. Foram realizados cortes da forragem, com amostragens sistemáticas na diagonal de cada piquete. A cada $12 \mathrm{~m}$, um quadrado metálico de $1 \mathrm{~m}^{2}$ com um lado aberto foi posto sobre o solo e a forragem delimitada foi cortada a $30 \mathrm{~cm}$ de altura, totalizando seis cortes de forragem (24/ha) em cada piquete.

Da biomassa coletada em cada piquete foi retirada uma subamostra, que foi pesada, antes e após a secagem em estufa com ventilação forçada $\left(55^{\circ} \mathrm{C}\right.$ por 72 horas), para a determinação de seu teor de matéria seca. Multiplicando-se o peso da biomassa coletada em $6 \mathrm{~m}^{2} \times$ a extrapolação para 1 ha $(10.000 \div 6) \times$ o teor de MS da biomassa coletada, foi obtida a estimativa da matéria seca residual, em $\mathrm{kg} / \mathrm{ha}$ de MS.

$\mathrm{Na}$ análise estatística foram consideradas separadamente as épocas seca e chuvosa. Os efeitos de épocas, blocos, forrageiras e níveis de irrigação foram considerados fixos e o efeito de repetição dentro de bloco, forrageiras e níveis de irrigação, aleatórios.

A análise referente à época seca foi efetuada segundo o modelo:

$\mathrm{Y}_{\mathrm{ijklm}}=\mu+\mathrm{A}_{\mathrm{i}}+\mathrm{B}_{\mathrm{j}}+\mathrm{F}_{\mathrm{k}}+\mathrm{I}_{1}+\mathrm{AB}_{\mathrm{ij}}+\mathrm{AF}_{\mathrm{ik}}+\mathrm{AI}_{\mathrm{il}}+\mathrm{BF}_{\mathrm{jk}}+$
$\mathrm{BI}_{\mathrm{j} \mathrm{l}}+\mathrm{FI}_{\mathrm{kl}}+\mathrm{ABF}_{\mathrm{ijk}}+\mathrm{ABI}_{\mathrm{ijl}}+\mathrm{AFI}_{\mathrm{ikl}}+\mathrm{BFI}_{\mathrm{jkl}}+\mathrm{ABFI}_{\mathrm{ijkl}}$
$+\mathrm{R}\left(\mathrm{B}_{\mathrm{j}} \mathrm{F}_{\mathrm{k}} \mathrm{I}_{1}\right)_{\mathrm{m}}+\mathrm{e}_{\mathrm{ijklm}}$,

em que: $Y_{i j k l m}=$ informações referentes à repetição $\mathrm{m}$, nível de irrigação 1 , forrageira $\mathrm{k}$, bloco $\mathrm{j}$, no ano $\mathrm{i} ; \mu=$ média geral; $A_{i}=$ efeito do ano $\mathrm{i}(\mathrm{i}=1$ e 2$)$; $\mathrm{B}_{\mathrm{j}}=$ efeito do bloco $\mathrm{j}$ $(\mathrm{j}=1,2 \mathrm{e} 3) ; \mathrm{F}_{\mathrm{k}}=$ efeito da forrageira $\mathrm{k}(\mathrm{k}=1$ para mombaça e 2, napier); $\mathrm{I}_{1}=$ efeito do nível de irrigação $\mathrm{l}(\mathrm{l}=1,2) ; \mathrm{AB}_{\mathrm{ij}}=$ efeito da interação do ano i e o bloco $\mathrm{j} ; \mathrm{AF}_{\mathrm{ik}}=$ efeito da interação do ano i e a forrageira $\mathrm{k} ; \mathrm{AI}_{\mathrm{il}}=$ efeito da interação ano $\mathrm{i} \times$ nível de irrigação $1 ; \mathrm{BF}_{\mathrm{jk}}=$ efeito da interação bloco $\mathrm{j} \times$ forrageira $\mathrm{k} ; \mathrm{BI}_{\mathrm{jl}}=$ efeito da interação do bloco $\mathrm{j}$ e o nível de irrigação $1 ; \mathrm{FI}_{\mathrm{kl}}=$ efeito da interação da forrageira k e o nível de irrigação $1 ; \mathrm{ABF}_{\mathrm{ijk}}=$ efeito da interação do ano $\mathrm{i}$, bloco $\mathrm{j}$, e forrageira $\mathrm{k} ; \mathrm{ABI}_{\mathrm{ijl}}=$ efeito da interação do ano i, bloco j e nível de irrigação $1 ; \mathrm{AFI}_{\mathrm{ikl}}=$ efeito da interação do ano $\mathrm{i}$, forrageira ke nível de irrigação $1 ; \mathrm{BFI}_{\mathrm{jkl}}=$ efeito da interação do bloco j, forrageira k e nível de irrigação $1 ; \mathrm{ABFI}_{\mathrm{ijkl}}=$ efeito da interação do ano $i$, bloco $j$, forrageira $k$ e nível de irrigação $1 ; \mathrm{R}_{\mathrm{m}}\left(\mathrm{B}_{\mathrm{j}} \mathrm{F}_{\mathrm{k}} \mathrm{I}_{1}\right)=$ efeito da repetição $m$ dentro de bloco, forrageira e nível de irrigação $(m=1,2$ e 3), utilizado na análise de variância como erro termo para os efeitos de bloco, forrageira e nível de irrigação; $\mathrm{e}_{\mathrm{ijklm}}=$ erro aleatório, associado a cada observação, pressuposto normal e independentemente distribuído, com média zero e variância $\sigma^{2}$.

Como só foi avaliada uma época chuvosa, foram retirados do modelo acima, para essa época, o efeito de ano e as interações em que se incluiu a variável ano. Os resultados foram submetidos à análise de variância, pelo procedimento PROC GLM do SAS.

\section{Resultados e Discussão}

A disponibilidade de matéria seca total do capim-napier foi maior que a do capim-mombaça $(\mathrm{P}<0,05)$ nas duas épocas avaliadas (Tabela 2) e está relacionada às maiores quantidades de colmo produzidas por essa forrageira nas épocas seca e chuvosa; as médias de porcentagem de 
lâminas foliares para essa forrageira foram de 32,7 e 30,8\%, respectivamente, para o capim irrigado e o não-irrigado, enquanto, no capim-mombaça, essas médias foram de 68,2 e $58,3 \%$, respectivamente (Tabela 3 ). Tanto o capimmombaça quanto o capim-napier apresentaram maior disponibilidade de matéria seca total quando submetidos à irrigação $(\mathrm{P}<0,05)$, nas duas épocas (Tabela 2).

A alta proporção de colmo do capim-napier nas duas épocas e a proporção elevada de colmo no capim-mombaça na época chuvosa (Tabela 3 ) sugerem que o ciclo de pastejo poderia ter sido mais curto nas duas épocas para o capimnapier e nas águas para o capim-mombaça.

Com base em duas pesquisas com os capins Marandu (Brachiaria brizantha cv. Marundu) e Mombaça, Da Silva \& Nascimento Jr. (2008) concluíram que plantas forrageiras tropicais e subtropicais, de forma semelhante às forrageiras temperadas, iniciam o processo de rebrotação e produção de forragem pelo acúmulo de tecidos provenientes de folhas.
Somente quando ocorre restrição de luminosidade (acima de $95 \%$ de interceptação de luz do dossel forrageiro) ou quando no início do florescimento é que as plantas iniciam o alongamento de colmos, responsável pelo sombreamento e pela senescência de folhas basais, resultando no aumento da proporção de colmos e material morto na massa de forragem pré-pastejo.

Possivelmente, a adoção de um manejo mais frequente, com redução do período de descanso, resultasse em menor alongamento dos colmos, elevando a proporção de lâminas foliares e a qualidade da forragem, conforme observado por Santos et al. (1999).

Neste trabalho, por imposição das condições disponíveis para a instalação do experimento e por não haver referência no Norte Fluminense sobre o comportamento das duas forrageiras envolvidas no estudo, adotou-se um ciclo de pastejo único e fixo para as duas forrageiras, o qual se situou nos limites observados para ambas na literatura

Tabela 2 - Disponibilidade média de matéria seca total e de matéria seca verde, de matéria seca residual nos capins napier e mombaça sob irrigação nas épocas seca e chuvosa

\begin{tabular}{|c|c|c|c|}
\hline \multirow[t]{2}{*}{ Forrageira } & \multicolumn{2}{|c|}{ Nível de irrigação } & \multirow[t]{2}{*}{ Média } \\
\hline & Irrigado & Não Irrigado & \\
\hline
\end{tabular}

Época seca

Disponibilidade de material seca total $(\mathrm{kg} / \mathrm{ha})$

Napier

Mombaça

Média

Disponibilidade matéria seca verde $(\mathrm{kg} / \mathrm{ha})$

Napier

Mombaça

Média

Matéria seca residual $(\mathrm{kg} / \mathrm{ha})$

Napier

Mombaça

Média

Época chuvosa

Disponibilidade de matéria seca total $(\mathrm{kg} / \mathrm{ha})$

Napier

Mombaça

Média

Disponbilidade de matéria seca verde $(\mathrm{kg} / \mathrm{ha})$

Napier

Mombaça

Média

Matéria seca residual ( $\mathrm{kg} / \mathrm{ha})$

Napier

Mombaça

Média

$$
\begin{aligned}
& 6.556,1 \pm 166,9 \\
& 4.426,5 \pm 166,9 \\
& 5.491,3 \pm 118,0 \mathrm{~A}
\end{aligned}
$$

$5.929,8 \pm 141,1$

$3.271,4 \pm 141,1$

$4.600,6 \pm 99,8 \mathrm{~A}$

$3.388,1 \pm 85,4$
$2.015,9 \pm 85,4$
$2.702,0 \pm 60,36 \mathrm{~A}$
$5.332,1 \pm 166,9$

$2.975,7 \pm 166,9$

$4.153,9 \pm 118,0 \mathrm{~B}$

$4.795,6 \pm 141,1$

$2.101,3 \pm 141,1$

$3.448,5 \pm 99,8 \mathrm{~B}$

$2.867,9 \pm 85,4$

$1.678,8 \pm 85,4$

$2.273,4 \pm 60,4 \mathrm{~B}$
$5.944,1 \pm 118,0 \mathrm{a}$

$3.701,0 \pm 118,0 \mathrm{~b}$

$5.362 .7 \pm 99,8 \mathrm{a}$

$2.686,3 \pm 99,8 b$

\footnotetext{
${ }^{1}$ Médias referentes a duas épocas secas e uma chuvosa, cada uma com 4 ciclos de pastejo, com 4 dias de ocupação e 32 dias de descanso.

Médias seguidas de letras maiúsculas diferentes nas linhas e minúsculas nas colunas diferem-se pelo teste F.
}

$$
\begin{aligned}
& 7.663,5 \pm 298,9 \\
& 6.746,2 \pm 298,9
\end{aligned}
$$$$
7.204,9 \pm 211,3 \mathrm{~A}
$$

$7.335,5 \pm 325,0$

$5.898,4 \pm 325,0$

$6.617,0 \pm 229,8 \mathrm{~B}$

$6.650,1 \pm 298,9$

$5.427,9 \pm 298,9$

$6.039,0 \pm 211,3 \mathrm{~B}$
$7.897,2 \pm 229,8 \mathrm{a}$ $6.747,2 \pm 229,8 b$

$7.156,8 \pm 211,3 \mathrm{a}$ $6.087,1 \pm 211,3 \mathrm{~b}$

$3.633,0 \pm 99,3 \mathrm{a}$

$2.819,4 \pm 99,3 \mathrm{~b}$

$\begin{array}{lll}3.728,6 \pm 140,4 & 3.537,3 \pm 140,4 & 3.633,0 \pm 99,3 \mathrm{a} \\ 3.142,7 \pm 140,4 & 2.496,0 \pm 140,4 & 2.819,4 \pm 99,3 \mathrm{~b}\end{array}$

$3.128,0 \pm 60,4 \mathrm{a}$ $1.847,4 \pm 60,4 \mathrm{~b}$ 
(Brâncio et al., 2003; Martins et al., 2004). Os resultados indicam, entretanto, necessidade de revisão desse conceito em trabalhos futuros.

Diferentes abordagens têm sido propostas, mais recentemente, para o estabelecimento do momento de entrada do animal no piquete, que resultam em durações variáveis do período de descanso e do ciclo de pastejo. Assim, Alexandrino et al. (2005) definiram os períodos de descanso para o capim-mombaça em relação ao tempo necessário para expansão de 2,5 e 3,5 folhas/perfilho. Os períodos de descanso definidos dessa forma variaram, nos diferentes ciclos de pastejo, de 24 a 39 dias e de 29 a 46 dias para a expansão, respectivamente, de 2,5 e 3,5 folhas. O critério de 2,5 folhas expandidas proporcionou os maiores ganhos de peso por animal e por área.

A tendência atual é recomendar, para forrageiras tropicais e subtropicais em regime de desfolhação intermitente, como condição de pré-pastejo, o nível de $95 \%$ de interceptação luminosa pelo dossel, coincidindo com as recomendações estabelecidas para forrageiras temperadas. Entretanto, quando se adota o índice de interceptação luminosa de $95 \%$, não é possível o uso de períodos de descanso fixos (Da Silva \& Nascimento Jr., 2008).

É provável que, em exploração comercial com menor flexibilidade quanto à disponibilidade de piquetes - de forma a possibilitar os necessários ajustes na duração dos períodos de descanso, mantendo sempre $95 \%$ de interceptação luminosa no pré-pastejo - seja necessário utilizar valores médios fixos para a duração de períodos de descanso e ajustes na carga animal durante o ano, adequados às estações e às forrageiras, o que possibilitaria a manutenção de valores médios de interceptação luminosa mais próximos de $95 \%$.

Os valores de disponibilidade de matéria seca total verificados com irrigação, em ambas as forrageiras, foram superiores aos obtidos sem irrigação. Foram observados aumentos na disponibilidade de matéria seca total para o capim-napier e o capim-mombaça, de 23 e 48\%, respectivamente, na época seca e de 15 e $29 \%$ na época chuvosa. Esses resultados permitem inferir que o déficit hídrico na época seca seria provavelmente o principal limitante do crescimento do capim-mombaça na região. Por outro lado, no capim-napier, o menor aumento percentual da produção de biomassa em resposta à irrigação pode ser em grande parte explicado pela sua alta produção na seca, quando não irrigado, correspondente a $73 \%$ da disponibilidade de matéria seca total do período das águas e a $42 \%$ da produção total das duas épocas. Outros fatores, como temperatura e luminosidade, poderiam igualmente ter influência.
Os aumentos da disponibilidade de matéria seca total decorrentes da irrigação para capim-napier situaram-se abaixo do aumento médio de $26 \%$ relatado por Ghelfi Filho (1972) para as duas épocas do ano. Por sua vez, Souza et al. (2005), avaliando cinco cultivares de P. maximum, encontraram resposta positiva à irrigação na produção de matéria seca ( $40 \%$ no ano), apenas no período de outubro a junho. Nos meses de julho, agosto e setembro, não houve efeito de irrigação.

A sensibilidade das forrageiras tropicais às baixas temperaturas foi constatada por Lopes et al. (2005), que não verificaram efeito da irrigação, em capim-elefante no período de abril a setembro, no qual a média das temperaturas mínimas situou-se em torno de $12{ }^{\circ} \mathrm{C}$. Também Aveiro et al. (1991) avaliaram o efeito da irrigação no capim-elefante, cv. Cameroon, e não verificaram crescimento da forrageira nos meses de inverno, em virtude da ocorrência de geadas. Nos períodos de primavera, verão e outono, a irrigação proporcionou aumento de $42 \%$ na produção total de matéria verde.

Os resultados desta pesquisa indicam que as temperaturas mínimas nos meses de seca, no Norte Fluminense, superiores a $15,5^{\circ} \mathrm{C}$, permitem satisfatório desenvolvimento das forrageiras avaliadas, o que pode viabilizar economicamente a irrigação nos meses de seca, entretanto, uma avaliação econômica precisa ser realizada para maiores inferências acerca da viabilidade da irrigação.

Em consonância com os valores de disponibilidade de matéria seca total, a disponibilidade de matéria seca verde do capim-napier foi maior que a do capim-mombaça $(\mathrm{P}<0,05)$, e os valores obtidos com irrigação foram maiores que na ausência de irrigação $(\mathrm{P}<0,05)$ nas duas épocas. A disponibilidade de matéria seca verde do capim-napier superou em 99 e 18\% a do capim-mombaça nas épocas seca e chuvosa, respectivamente.

A diferença entre a disponibilidade de matéria seca total e matéria seca verde representa o material senescente e morto, cuja proporção foi mais baixa no capim-napier que no capim-mombaça na época seca ( $10 \%$ no capim-napier e $27 \%$ no capim-mombaça), em proporções semelhantes nas duas forrageiras na época chuvosa $(10 \%$ em ambas forrageiras).

As taxas de aparecimento, alongamento e senescência foliares variam de acordo com a espécie, o cultivar, a estação do ano e os parâmetros de manejo, como: altura do relvado e nível de oferta da forragem; as taxas de aparecimento de folhas e de perfilhamento variam inversamente com o nível de oferta, enquanto as taxas de alongamento e senescência crescem com a oferta (Gomide, 1997). 
Existe um sincronismo entre o aparecimento e a morte de folhas, de modo que o número de folhas mantidas vivas em cada perfilho permanece constante após algum tempo (Lemaire \& Chapman, 1996). Esse número depende da taxa de aparecimento e do tempo de vida de cada folha. Depois de atingida a condição de equilíbrio em um dossel, o número de folhas vivas por perfilho fica relativamente constante para plantas de mesmo cultivar ou espécie (Gomide, 1997). Hogdson et al. (1981) definiram o acúmulo de forragem da pastagem como um processo dinâmico, resultante do balanço entre o crescimento e a senescência dos tecidos. Com o propósito de melhorar a produção de forragem, tanto em lotação contínua quanto intermitente, o manejo de pastejo deve ter como objetivo reter área foliar antes da senescência (Parsons, 1998). O material senescente e morto representa parte da biomassa não selecionada pelo animal e, quando em altas proporções, pode indicar que o período de descanso deva ser reduzido.

Não se verificou efeito de interação de forrageira e irrigação $(\mathrm{P}>0,05)$ sobre a matéria seca residual nas épocas seca e chuvosa. Os maiores valores foram observados no capim-napier, em relação ao capim-mombaça, e na presença de irrigação, em relação à não-irrigação (Tabela 2). Os maiores valores de matéria seca residual observados no capim-napier, irrigado ou não, em relação ao capimmombaça, estão ligados ao seu maior porte, com diferenciação e alongamento mais precoce dos colmos, que, por serem mais vigorosos, têm apenas suas porções terminais ingeridas pelos animais, emitindo posteriormente perfilhos axilares e elevando os pontos de crescimento. A irrigação, ao proporcionar maior crescimento e alongamento de colmos, promoveu aumento na matéria seca residual.

A matéria seca residual é altamente influenciada pela pressão de pastejo e pela duração do período de descanso, entre outros fatores, e seus valores (Tabela 2) são médias para os períodos de seca e chuvoso, determinados por corte do resíduo a $30 \mathrm{~cm}$ do solo, o que impede visualizar os aumentos cumulativos na matéria seca residual nas forrageiras avaliadas com a elevação dos pontos de crescimento nos sucessivos ciclos de pastejo.

É possível, especialmente para o capim-mombaça, que fosse vantajosa a adoção de período de descanso mais curto, mantendo-se resíduo pós pastejo mais baixo, o que poderia estimular o perfilhamento basal e proporcionar forragem de maior valor nutritivo aos animais. Nesse sentido, Aguiar (2000) recomendou que, no manejo intensivo de forrageiras da espécie $P$. maximum, o resíduo pós-pastejo não deve ser superior a $1.500 \mathrm{~kg} / \mathrm{ha}$ de $\mathrm{MS}$, para possibilitar a penetração de luz e estimular o perfilhamento basilar, que é fundamental para forrageiras dessa espécie.
O consumo de forragem pelo animal em pastejo depende não apenas da composição bromatológica do pasto, mas também e especialmente das características estruturais da vegetação, como relação lâmina foliar/colmo, altura, densidade e disponibilidade da forragem. Além disso, conforme salientaram Pinto et al. (1994), elevada relação lâmina:colmo é uma característica de grande importância, tanto do ponto de vista nutricional, por representar forragem de maiores teor de proteína, digestibilidade e consumo, quanto para o manejo da forrageira, por conferir às gramíneas maior tolerância ao corte, ao coincidir com um momento de desenvolvimento fenológico em que os meristemas apicais encontram-se mais próximos ao solo, portanto, menos vulneráveis à eliminação.

Avaliando a porcentagem de folhas, observou-se, na época chuvosa, efeito significativo apenas da forrageira $(\mathrm{P}<0,05)$, mas não houve efeito de irrigação $(\mathrm{P}>0,05)$. Na época seca, ocorreram efeitos da interação forrageira $\times$ irrigação e efeitos médios de forrageira e de irrigação $(\mathrm{P}<0,05)$ : nas forrageiras irrigadas, a proporção de folhas foi maior $(\mathrm{P}<0,05)$ que naquelas não-irrigadas. Nas duas épocas, a proporção de folhas do capim-mombaça foi maior $(\mathrm{P}<0,05)$ que no capim-napier, superando-o em 109\% na época seca e em $89 \%$ na época chuvosa (Tabela 3).

Os altos níveis de adubação utilizados propiciaram o crescimento rápido do capim-napier, mesmo quando não irrigado durante a seca, conforme demonstram os valores de DMST, obtidos por corte a $30 \mathrm{~cm}$ do solo (Tabela 2). Uma característica marcante da espécie é a tendência de desviar nutrientes para o alongamento dos colmos, mantendo a produção de lâminas estabilizada após certo período de crescimento. A conjunção dos dois fatores resultou em proporções baixas de lâminas foliares nesta forrageira, nas épocas seca e chuvosa.

Em pesquisa com o capim-elefante, com duração de dois anos, Lopes et al. (2005) verificaram no primeiro ano proporções de lâminas foliares bem altas, enquanto no segundo ano, as proporções foram similares às deste trabalho, embora o corte para a amostragem tenha sido feito a $80 \mathrm{~cm}$ do solo.

Com base nesses resultados, pode-se inferir que, nas condições em que se realizou o experimento, o capimnapier deve ser manejado com maior frequência, de forma a estimular o perfilhamento e possibilitar maior oferta de folhas aos animais.

A maior proporção de folhas observada no capimmombaça está relacionada ao seu hábito de crescimento com pouco alongamento do colmo e maior perfilhamento basal em relação ao capim-elefante. Assim, o corte a $30 \mathrm{~cm}$ 
Tabela 3 - Porcentagem de lâminas foliares, altura do dossel e densidade volumétrica da forragem dos capins napier e mombaça irrigados ou não nas épocas seca e chuvosa ${ }^{1}$

\begin{tabular}{|c|c|c|c|}
\hline Forrageira & \multicolumn{2}{|c|}{ Nível de irrigação } & Média \\
\hline \multicolumn{4}{|l|}{ Época seca } \\
\hline \multicolumn{4}{|c|}{ Lâminas foliares (\%) } \\
\hline Napier & $34,0 \pm 1,05 \mathrm{Ab}$ & $31,5 \pm 1,05 \mathrm{Ab}$ & $32,7 \pm 0,75 b$ \\
\hline Mombaça & $71,0 \pm 1,05 \mathrm{Aa}$ & $65,4 \pm 1,05 \mathrm{Ba}$ & $68,2 \pm 0,75 a$ \\
\hline \multicolumn{4}{|l|}{ Altura $(\mathrm{cm})$} \\
\hline Napier & $128,0 \pm 1,95$ & $124,3 \pm 1,95$ & $126,1 \pm 1,38 \mathrm{a}$ \\
\hline Mombaça & $90,3 \pm 1,95$ & $78,5 \pm 1,95$ & $84,4 \pm 1,38 b$ \\
\hline Média & $109,2 \pm 1,38 \mathrm{~A}$ & $101,4 \pm 1,38 \mathrm{~B}$ & \\
\hline \multicolumn{4}{|c|}{ Densidade $(\mathrm{kg} / \mathrm{cm})$} \\
\hline Napier & $71,2 \pm 3,85$ & $60,5 \pm 3,85$ & $65,9 \pm 2,43 a$ \\
\hline Mombaça & $72,0 \pm 3,85$ & $60,9 \pm 3,85$ & $66,5 \pm 2,43 a$ \\
\hline \multicolumn{4}{|c|}{ Lâminas foliares (\%) } \\
\hline Napier & $31,2 \pm 2,41$ & $30,5 \pm 2,41$ & $30,8 \pm 1,70 b$ \\
\hline Mombaça & $59,3 \pm 2,41$ & $57,4 \pm 2,41$ & $58,3 \pm 1,70 \mathrm{a}$ \\
\hline Média & $45,2 \pm 1,70 \mathrm{~A}$ & $43,9 \pm 1,70 \mathrm{~A}$ & \\
\hline \multicolumn{4}{|c|}{ Altura (cm) } \\
\hline Napier & $148,1 \pm 3,41$ & $142,7 \pm 3,41$ & $145,4 \pm 2,41 \mathrm{a}$ \\
\hline Mombaça & $138,8 \pm 3,41$ & $121,6 \pm 3,41$ & $130,2 \pm 2,41 b$ \\
\hline Média & $143,4 \pm 2,41 \mathrm{~A}$ & $132,1 \pm 2,41 \mathrm{~B}$ & \\
\hline \multicolumn{4}{|c|}{ Densidade $(\mathrm{kg} / \mathrm{cm})$} \\
\hline Napier & $71,8 \pm 3,65$ & $66,8 \pm 3,65$ & $69,3 \pm 2,82 a$ \\
\hline Mombaça & $70,5 \pm 3,65$ & $68,6 \pm 3,65$ & $69,5 \pm 2,82 a$ \\
\hline Média & $71,2 \pm 2,82 \mathrm{~A}$ & $67,7 \pm 2,82 \mathrm{~A}$ & \\
\hline
\end{tabular}

${ }^{1}$ Médias referentes a duas épocas secas e uma chuvosa, cada uma com 4 ciclos de pastejo, com 4 dias de ocupação e 32 dias de descanso.

Médias seguidas de letras maiúsculas diferentes nas linhas e minúsculas nas colunas diferem-se pelo teste de t.

do solo, propiciou maior colheita de folhas no capimmombaça e menor no capim-napier.

A irrigação durante a época seca promoveu o aumento da proporção de lâminas foliares nas duas forrageiras, o que confirma relatos de Corsi et al. (1998) de que a falta de água impõe limitações sobre a taxa de expansão de folhas, o número de folhas por perfilho e o número de perfilhos. $\mathrm{Na}$ época chuvosa, a irrigação não influenciou $(\mathrm{P}>0,05)$ a proporção de lâminas foliares das duas forrageiras, o que indica períodos transitórios de deficiência hídrica podem não afetar essa característica.

As proporções de lâminas foliares no capim-napier, irrigado ou não, mantiveram-se praticamente constantes nas duas épocas, assim como as proporções de material senescente e colmo. A variação sazonal de produção dessa forrageira foi relativamente pequena em comparação às produções de biomassa das épocas seca e chuvosa dentro de mesmo nível de irrigação. Aparentemente, esse fato possibilitou a manutenção de proporções constantes dos vários componentes da planta, durante o ano.

A redução de cerca de $17 \%$ na proporção de folhas no capim-mombaça na época chuvosa reflete o maior alongamento dos colmos nessa época, sugerindo que a forrageira poderia ser manejada com maior frequência, com redução do período de descanso. Além disso, o florescimento das plantas a partir de março possivelmente influenciou o alongamento dos colmos.

Ao avaliar a altura do dossel, verificou-se maior altura $(\mathrm{P}<0,05)$ nos capins sob irrigação, em relação aos não irrigados, e no capim-napier, em relação ao capim-mombaça, nas épocas seca e chuvosa (Tabela 3). Apesar do aumento na altura, não houve redução da proporção de folhas das forrageiras, apesar do ligeiro acréscimo, embora nãosignificativo, na proporção de lâminas foliares das forrageiras irrigadas na seca.

As maiores alturas observadas no capim-napier são decorrência normal de seu maior porte em relação ao capimmombaça. Durante a época chuvosa, o capim-mombaça apresentou altura média elevada, o que confirma que essa forrageira poderia ter sido manejada com maior frequência, de forma a estimular o perfilhamento basal, o que poderia melhorar a qualidade da forragem disponível aos animais.

Não houve efeito de interação $(P>0,05)$ de forrageira e irrigação para a densidade volumétrica (DV) dos capins 
napier e mombaça nas duas épocas estudadas (Tabela 3). A irrigação elevou $(\mathrm{P}<0,05)$ a densidade volumétrica das duas forrageiras na época seca, mas não teve efeito $(\mathrm{P}>0,05)$ na época chuvosa.

Penati (2003) encontrou densidades volumétricas de 94, 102 e $99 \mathrm{~kg} / \mathrm{ha} / \mathrm{cm}$ de MS em capim-tanzânia irrigado mantido com 1.000, 2.500 e $4.000 \mathrm{~kg} / \mathrm{ha}$ de MSV residual, respectivamente, mas não notou diferença entre densidades volumétricas. Esses maiores valores estão relacionados ao fato de a densidade volumétrica ter sido determinada pela DMST, e não da DMSV, e possivelmente foram influenciados pela menor altura do capim-tanzânia.
Não houve efeito de interação forrageira $\times$ nível de irrigação $(\mathrm{P}>0,05)$ sobre os teores de MS na época seca e de MO e PB nas épocas seca e chuvosa (Tabela 4). Para o teor de MS na época chuvosa, apesar do efeito de interação de forrageira e nível de irrigação, houve efeito médio $(\mathrm{P}<0,05)$ de forragem e de nível de irrigação. O capim-mombaça apresentou maiores teores $(\mathrm{P}<0,05)$ de MS e de MO e menores teores de $\mathrm{PB}$ nas duas épocas do ano. A irrigação reduziu $(\mathrm{P}<0,05)$ o teor de MS das duas forrageiras, nas épocas seca e chuvosa, e o teor de MO, na época chuvosa, e não teve influência $(\mathrm{P}>0,05)$ nos teores de $\mathrm{PB}$, nas duas épocas, e no teor de MO na época seca.

Tabela 4 - Composição química das lâminas foliares e dos capins napier e mombaça, irrigados ou não, nas épocas seca e chuvosa ${ }^{1}$

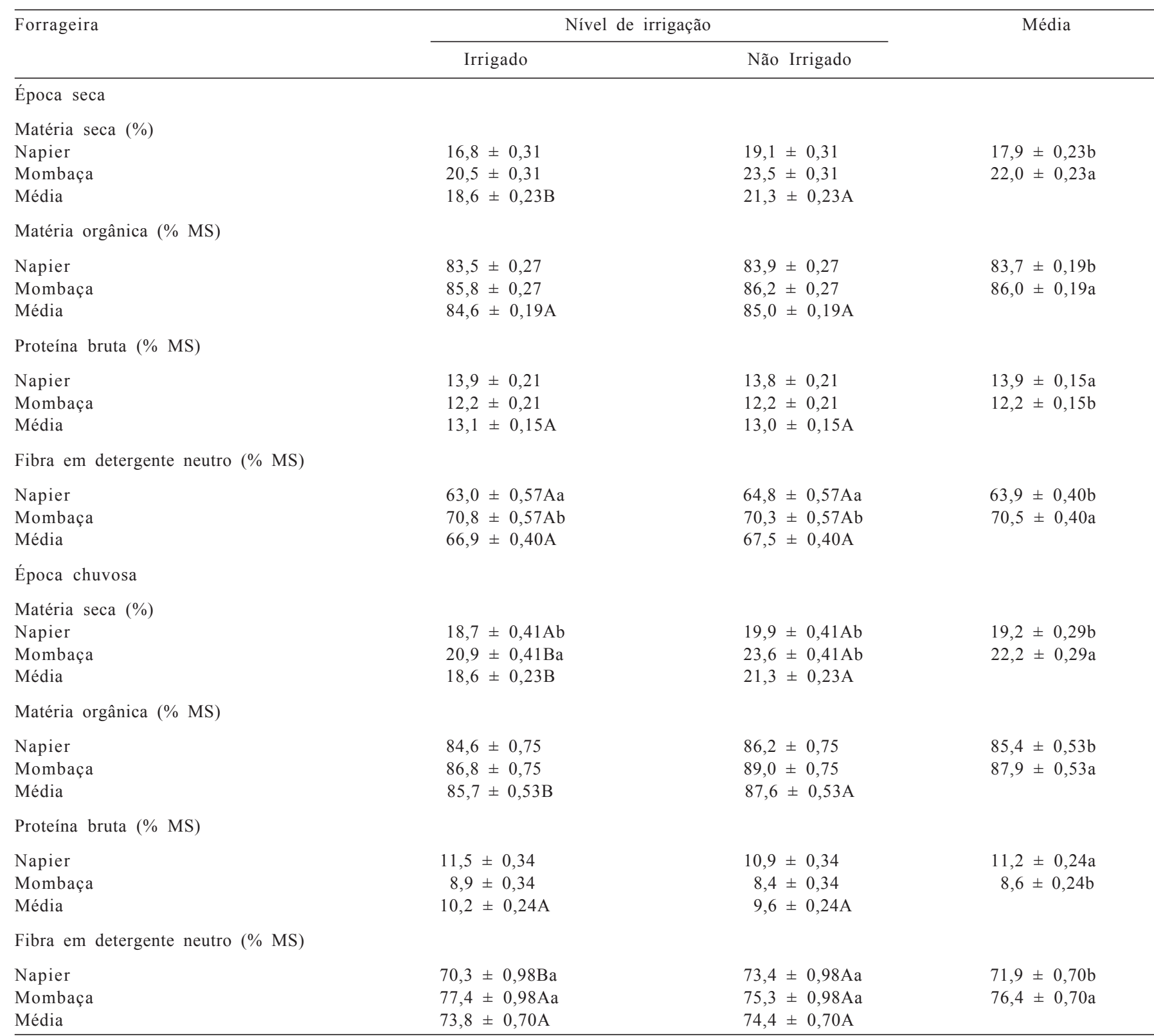

\footnotetext{
${ }^{1}$ Médias referentes a duas épocas secas e uma chuvosa, cada uma com 4 ciclos de pastejo, 4 dias de ocupação e 32 dias de descanso.
} Médias seguidas de letras maiúsculas diferentes nas linhas e minúsculas nas colunas diferem-se pelo teste de t. 
Nos teores de FDN, verificou-se efeito da interação de forrageira $\times$ irrigação $(\mathrm{P}<0,05)$ e efeito médio de forrageira, nas épocas seca e chuvosa (Tabela 4). O teor de FDN do capim-mombaça foi, nas duas épocas (seca e chuvosa), mais elevado $(\mathrm{P}<0,05)$ que o capim-napier. No capim-napier não-irrigado, o teor de FDN foi menor $(\mathrm{P}<0,05)$ que o do irrigado na época chuvosa, embora a irrigação tenha exercido pequena influência sobre o teor de FDN das duas gramíneas, nas duas épocas. Pesquisando a influência da irrigação sobre os teores de PB e FDN da lâmina foliar do capimnapier, Lopes et al. (2005) não verificaram efeito da irrigação na época seca do ano. Entretanto, quando consideraram a média do ano todo, verificaram maiores teores de FDN e menores teores de PB no capim irrigado, o que atribuíram ao efeito de diluição do nitrogênio, ocasionado pelo aumento da parede celular, decorrente do maior crescimento das plantas no período quente do ano

Neste trabalho, o efeito pode ter sido semelhante nas duas forrageiras. Apesar de as duas épocas do ano terem sido avaliadas separadamente, houve redução de 19,4 e $29,4 \%$ nos teores de PB e aumento de 12,6 e $8,2 \%$ nos teores de FDN, dos capins napier e mombaça, respectivamente, na época chuvosa, quando os capins tiveram crescimento mais vigoroso.

Os maiores teores de MS, MO e FDN e os menores teores de PB do capim-mombaça sugerem que as lâminas foliares dessa forrageira encontravam-se em estágio mais avançado de maturação, o que ressalta a necessidade de se avaliar melhor o período ideal de descanso dessa forrageira, principalmente no período chuvoso e em regiões com temperaturas elevadas e com o uso de irrigação.

\section{Conclusões}

Capim-napier e capim-mombaça são forrageiras que respondem bem à irrigação durante todo o ano, com maior produção de biomassa, proporção de folhas, altura e densidade volumétrica. O efeito da irrigação em capins napier e mombaça é mais pronunciado sobre a produção de biomassa foliar que sobre a composição química das folhas. A composição químico-bromatológica do capim-napier é melhor que a do capim-mombaça, embora o capim-mombaça apresente maior produção de biomassa de folhas verdes. Contudo, são necessários novos estudos para avaliar essas forrageiras em diferentes condições de manejo.

\section{Literatura Citada}

AGUIAR, A.P.A. Uso forrageiro do grupo Panicum em pastejo rotacionado para vacas leiteiras. In: SIMPÓSIO DE
FORRAGICULTURA E PASTAGENS: TEMAS EM EVIDÊNCIA, 2000, Lavras. Anais... Lavras: Universidade Federal de Lavras, 2000. p.149-177.

ALEXANDRINO, E.; GOMIDE, C.A.M.; CÂNDIDO, M.J.D. et al. Período de descanso e características estruturais do dossel e ganho de peso vivo de novilhos em pastagens de capim-mombaça sob lotação intermitente. Revista Brasileira de Zootecnia, v.15, n.5, p.384-292, 1986.

AlViM, M.J.; BOTREL, M.A.; NOVELLY, P.E. Produção de gramíneas tropicais e temperadas, irrigadas na época da seca. Revista Brasileira de Zootecnia, v.15, n.5, p.384-292, 1986.

AVEIRO, A.R.; SIEWERDT, L.; SILVEIRA JR., P. Capim-elefante: efeito da irrigação e das adubações mineral e orgânica. III produção total de matéria verde e sua distribuição sazonal. Revista Brasileira de Zootecnia, v.20, n.4, p.356-364, 1991

BRÂNCIO, P.A.; NASCIMENTO JR., D.; EUCLIDES, V.P.B. Avaliação de três cultivares de Panicum Maximum jacq. sob pastejo: composição da dieta, consumo de matéria seca e ganho de peso animal. Revista Brasileira de Zootecnia, v.32, n.5, p.1037-1044, 2003.

CARNEVALLI, R.A. Dinâmica da rebrotação de pastos de capim-mombaça submetidos a regimes de desfolhação intermitente. 2003. 136f. Tese (Doutorado em ciência Animal e Pastagens) - Escola Superior de Agricultura "Luiz de Queiroz"/ Universidade de São Paulo, Piracicaba, 2003.

COMISSÃO DE FERTILIDADE DO SOLO DO ESTADO DE MINAS GERAIS - CFSEMG. Recomendações para o uso de corretivos e fertilizantes em Minas Gerais; $5^{\text {a }}$ aproximação. Lavras: CFSEMG, 1999. 359p.

CORSI, M.; MARTHA JR., G.B. Manejo de pastagens para produção de carne e leite. In: SIMPÓSIO SOBRE MANEJO DE PASTAGENS, 15., 1988, Piracicaba. Anais... Piracicaba: Fundação de Estudos Agrários Luiz de Queiroz, 1998. p55-84.

CORSI, M.; SILVA, S.C.; FARIA, V.P. Princípios do manejo do capim-elefante sob pastejo. Informe Agropecuário, v.19, n.192, p.36-43, 1998.

DA SILVA, S.C.; NACIMENTO JR., D. Aspectos agronômicos para produção intensiva de leite em pasto. Cadernos Técnicos de Veterinária e Zootecnia, v.56, p.44-83, 2008.

GHELFI FILHO, H. Efeito da irrigação de verão e inverno sobre a produtividade do capim-elefante Napier (Pennisetum purpureum Schum). O Solo, v.64, n.2, p.72-79, 1972

GOMIDE, J.A. Formação e utilização de capineira. In: CARVALHO, M.M.; ALVIM, M.J.; XAVIER, D.F. et al. (Eds.) Capim-elefante: produção e utilização. Coronel Pacheco: Embrapa Gado de Leite, 1994. p.81-115.

GOMIDE, J.A. Morfogênese e análise de crescimento de gramíneas tropicais. In: SIMPÓSIO INTERNACIONAL SOBRE PRODUÇÃO ANIMAL EM PASTEJO, Viçosa, MG, 1997. Anais... Viçosa, MG: UFV, 1997. p.411-430.

GOMIDE, J.A. Morfogênese e análise de crescimento em gramíneas tropicais. In: SIMPÓSIO INTERNACIONAL SOBRE PRODUÇÃO ANIMAL EM PASTEJO, 1997, Viçosa, MG. Anais...Viçosa, MG: UFV, 1997. p.97-115.

HODGSON, J. Grazing management: science into practice. New York: John Wiley \& Sons, Longman Scientific \& Technical, 1990. 203p.

HODGSON, J.; BIRCHAM, J.S.; GRANT, S.A. et al. The influence of cutting and grazing management of herbage growth and utilization. In: SIMPOSIUM OF PLANT PHISIOLOGY AND Herbage PROduCtion, 1981, Nothingan. Proceedings... Belfast: British Grassland Society, 1981. p.51-62.

KÖPPEN, W. Climatologia. Buenos Aires: Panamericana, 1948 $478 \mathrm{p}$.

LEMAIRE, G.; CHAPMAN, D. Tissue flow in grazed plant comunities. In: HODGSON, J.; ILLIUS, A.W. (Eds) The ecology and management of grazing sytems. Wallingford: Cab International, 1996. p.3-36. 
LOPES, R.S.; FONSECA, D.M.; OLIVEIRA, R.A. et al. Efeito da irrigação na disponibilidade e composição bromatológica da massa seca de lâminas foliares de capim-elefante. Revista Brasileira de Zootecnia, v.34, n.1, p.20-29, 2005.

MARCELINO, K.R.A.; VILELA, L.; LEITE, G.G. et al. Manejo da adubação nitrogenada de tensões hídricas sobre a produção de matéria seca e índice de área foliar de tifton 85 cultivado no cerrado. Revista Brasileira de Zootecnia, v.32, n.2, p.268-275, 2003.

MARTINS, C.E.; CÓSER, A.C.; DERESZ, F. Formação e utilização de pastagem manejada em sistemas intensivos de produção de leite. Juiz de Fora: Embrapa Gado de Leite, 2004. p.1-10. (Circular técnica, 79).

MAYA, F.L.A. Produtividade e viabilidade econômica da recria e engorda de bovinos em pastagens adubadas intensivamente com e sem o uso da irrigação. 2003. 82f. Dissertação (Mestrado em Agronomia) - Escola Superior de Agricultura "Luiz de Queiroz"/ Universidade de São Paulo - ESALQ, Piracicaba, 2003.

PALIERAQUI, J.G.B.; FONTES, C.A.A.; RIBEIRO, E.G. et al. Influência da irrigação sobre a disponibilidade, a composição química, a digestibilidade e o consumo dos capins mombaça e napier. Revista Brasileira de Zootecnia, v.35, n.6, p.2381-2387, 2006.

PARSONS, A.J. The effect of season and management on the growth of grass swards. In: JONES, M.B.; LAZEMBY, A. (Eds) The grass crops: the physiological basis of production. London: Chapman \& Itall, 1988. p.129-177

PARSONS, A.J.; PENNING, P.D. The effect of duration of regrowth on photosynthesis, leaf death and the average rate of growth in a rotationally grazed sward. Grass and Forage Science, v.43 n.1, p.15-27, 1988 .

PENATI, M.A. Estudo do desempenho animal e produção do capim Tanzânia (Panicum maximum, Jacq.) em um sistema rotacionado de pastejo sob irrigação em três níveis de resíduo pós pastejo. 2003. 117f. Tese (Doutorado em Agronomia) - Escola Superior de Agricultura "Luiz de Queiroz"/ Universidade de São Paulo, Piracicaba, 2003.
PINTO, J.C.; GOMIDE, J.A.; MAESTRI, M. Produção de matéria seca e relação folha/caule de gramíneas forrageiras tropicais, cultivadas em vasos, com duas doses de nitrogênio. Revista Brasileira de Zootecnia, v.23, n.3, p.313-326, 1994.

RIBEIRO, E.G.; FONTES, C.A.A.; PALIERAQUI, J.G.B. et al Influência da irrigação durante as épocas seca e chuvosa na taxa de lotação, consumo e no desempenho de novilhos em pastagens de capim-elefante e capim-mombaça. Revista Brasileira de Zootecnia, v.37, n.9, p.1546-1554, 2008.

SANTOS, F.A.P. Manejo de pastagem de capim-elefante. In: PEIXOTO, A.M.; MOURA, J.C.; FARIA, V.P. (Eds) Volumoso para bovinos. 2.ed. Piracicaba: Fundação de Estudos Agrários Luiz de Queiroz, 1995. p.1-20.

SANTOS, P.M.; CORSI, M.; BALSALOBRE, M.A.A. Efeito da freqüência de pastejo e da época do ano sobre a produção e a qualidade em Panicum maximum cvs. Tanzânia e Mombaça. Revista Brasileira de Zootecnia, v.28, n.2, p.244-249, 1999

SBRISSIA, A.F.; SILVA, S.C. O ecossistema de pastagens e a produção animal. In: REUNIÃO ANUAL DA SOCIEDADE BRASILEIRA DE ZOOTECNIA, 38., 2001, Piracicaba. Anais... Piracicaba: Sociedade Brasileira de Zootecnia, 2001. (CD-ROM).

SILVA, D.J.; QUEIROZ, A.C. Análise de alimentos (métodos químicos e biológicos). 2.ed. Viçosa, MG: Universidade Federal de Viçosa. 2002. 235p.

SORIA, L.G.T. Produtividade do capim-tanzânia (Panicum maximum Jacq. cv. Tanzânia) em função da lâmina de irrigação e adubação nitrogenada. 2002. 170f. Tese (Doutorado em Agronomia) - Escola Superior de Agricultura "Luiz de Queiroz"/Universidade de São Paulo, Piracicaba, 2002.

SOUZA, E.M.; ISEPON, O.J.; ALVES, J.B. et al. Efeito da irrigação e adubação nitrogenada sobre a massa de forragem de cultivares de Panicum maximum Jacq. Revista Brasileira de Zootecnia, v.34, n.4, p.1146-1155, 2005.

WHITHEMAN, P.C. Tropical pasture Science. New York: Oxford University Press, 1980. 392p 